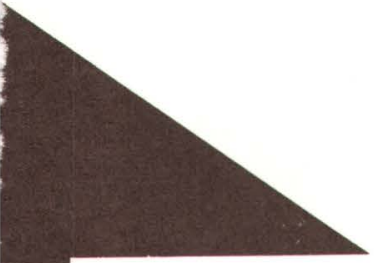

Fluvial-Sediment Discharge to the Oceans from the Conterminous United States

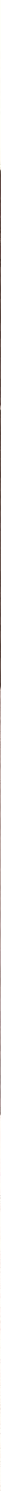


. 


\section{Fluvial-Sediment Discharge to the Oceans from the Conterminous United States}

By W. F. Curtis, J. K. Culbertson, and E. B. Chase

GEOLOGICAL SURVEY CIRCULAR 670

A contribution to the International

Hydrologic Decade 


\section{Department of the Interior}

WILLIAM P. CLARK, Secretary

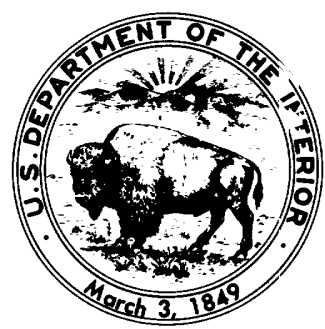

U.S. Geological Survey

Dallas L. Peck, Director

First printing 1973

Second printing 1984

Free on application to Distribution Branch, Text Products Section

U. S. Geological Survey, 604 South Pickett Street, Alexandria, VA 22304 


\section{CONTENTS}

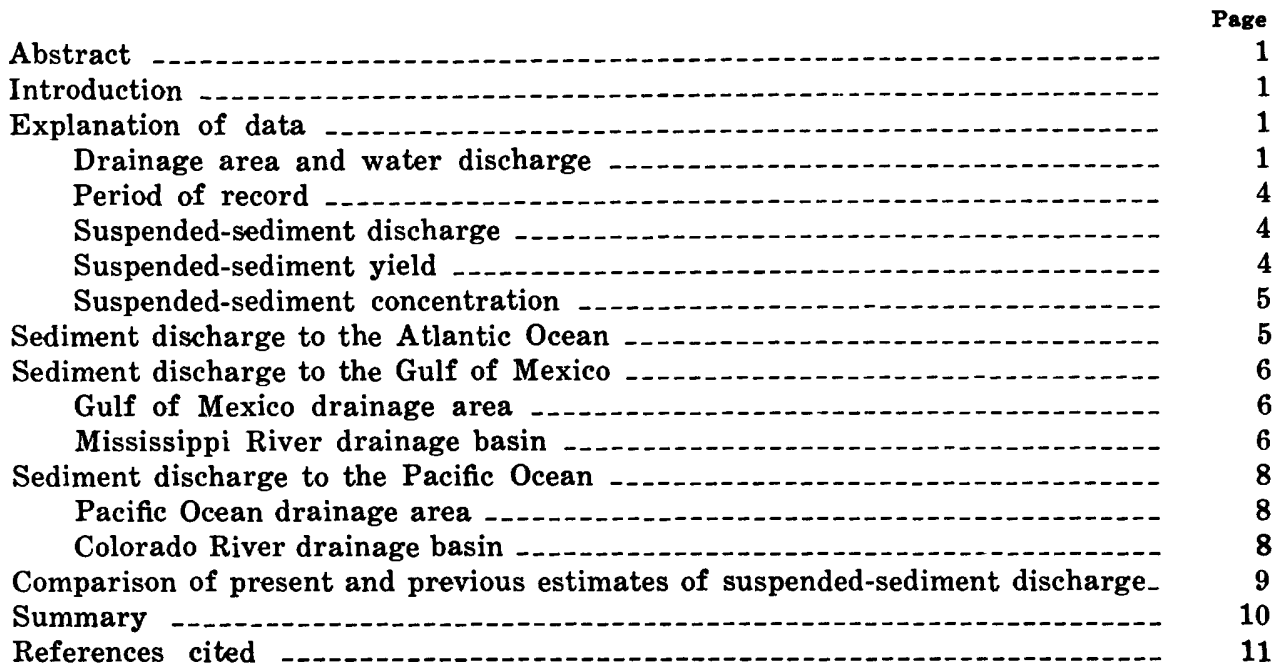

\section{ILLUSTRATIONS}

Cover. Space photograph of the Colorado River Delta, Baja California, showing fluvial sediment entering the Gulf of California. Flight of Apollo 9, March 1969. From NASA color infrared photograph AS9-26D-3781.

FIGURE 1. Map of the conterminous United States delineating drainage areas and location of sediment stations

2. Section of river showing zones of sampled and unsampled sediment

3. Sketch map of the lower Mississippi River drainage basin showing location of stations used to compute sediment discharge for the Mississippi River

Page

4. Hydrographs of water discharge and suspended-sediment discharge for the Colorado River at Yuma, Ariz., 1911-67

\section{TABLES}

TABLE 1. Historical suspended-sediment discharge data for the lower Mississippi River -...-..---.--

2. Comparison between present and past estimates of sediment yields for selected rivers discharging to the oceans from the conterminous United States

3. Summary of suspended-sediment discharge to the oceans from the conterminous United States_

4. Suspended-sediment discharge from the conterminous United States to the Atlantic Ocean,

Gulf of Mexico, and the Pacific Ocean

5. Identification of river stations used to compute sediment data 


\title{
Fluvial-Sediment Discharge to the Oceans from the Conterminous United States
}

\author{
By W. F. Curtis, J. K. Culbertson, and E. B. Chase
}

\begin{abstract}
This report is a contribution to the UNESCOsponsored project of the International Hydrological Decade called the World Water Balance. Annual fluvial-sediment discharge from the conterminous United States averages $491,449,600$ short tons, of which $14,204,000$ is discharged to the Atlantic Ocean, $378,179,000$ to the Gulf of Mexico, and 99,066,600 to the Pacific Ocean. Data from 27 drainage areas were used to estimate the average annual discharge, yield, and concentration of fluvial sediment. The data may be used to extrapolate part of the total world sediment yield to the marine environment.
\end{abstract}

\section{INTRODUCTION}

Sediment is defined as fragmental material derived primarily from the physical and chemical disintegration of rocks from the earth's crust. Once the sediment particles are detached, they may be transported either by gravity, wind, or water, or by a combination of these agents. When the transporting agent is water, the sediment is termed "fluvial sediment." The terms "fluvial sediment" and "suspended sediment" are used synonymously in this report to mean inorganic material that is transported in suspension by streams and rivers.

Knowledge of the amount of sediment transported by the various rivers of the world is important for many reasons. For example, reservoirs should be designed with enough space to store the sediment expected to accumulate in them and yet retain full effectiveness during their design life, and sediment yield can be an indication of the rate of erosion in the drainage basin. A summation of sediment yields by basins may indicate a regional, continental, and even an approximate world rate of crosion (Holeman, 1968). This report, which is a contribution to the UNESCO-sponsored project of the International Hydrological Decade called the World Water Balance, summarizes the quantity of fluvial sediment discharged to the Atlantic and Pacific Oceans and the Gulf of Mexico from the conterminous United States. Tre data given here may be useful to obtain the present total of world sediment yield to the marine environment.

The average annual amounts of suspended sediment discharged into the oceans from 27 major drainage areas were computed from suspended-sediment records from the files of the U.S. Geological Survey, the International Boundary and Water Commission, and the U.S. Army Corps of Engineers. These crainage areas and the location of selected sediment stations within the areas are shown in figure 1 . The data for these areas are given in table 4 in the back of the report, and an explanation of the data is given below.

\section{EXPLANATION OF DATA}

\section{DRAINAGE AREA AND WATER DISCHARGE}

The names, total drainage areas, and water discharges for the 27 drainage areas used in this report were taken from Wilson and Iseri (1967). Some of the data used in that report have since been revised (Alfonso Wilson and $\mathrm{K}$. T. Iseri, oral commun., 1971) and the revised data are identified in table 4 . W'ater and sediment discharged into the Great I.akes from the United States are not included in this report. 


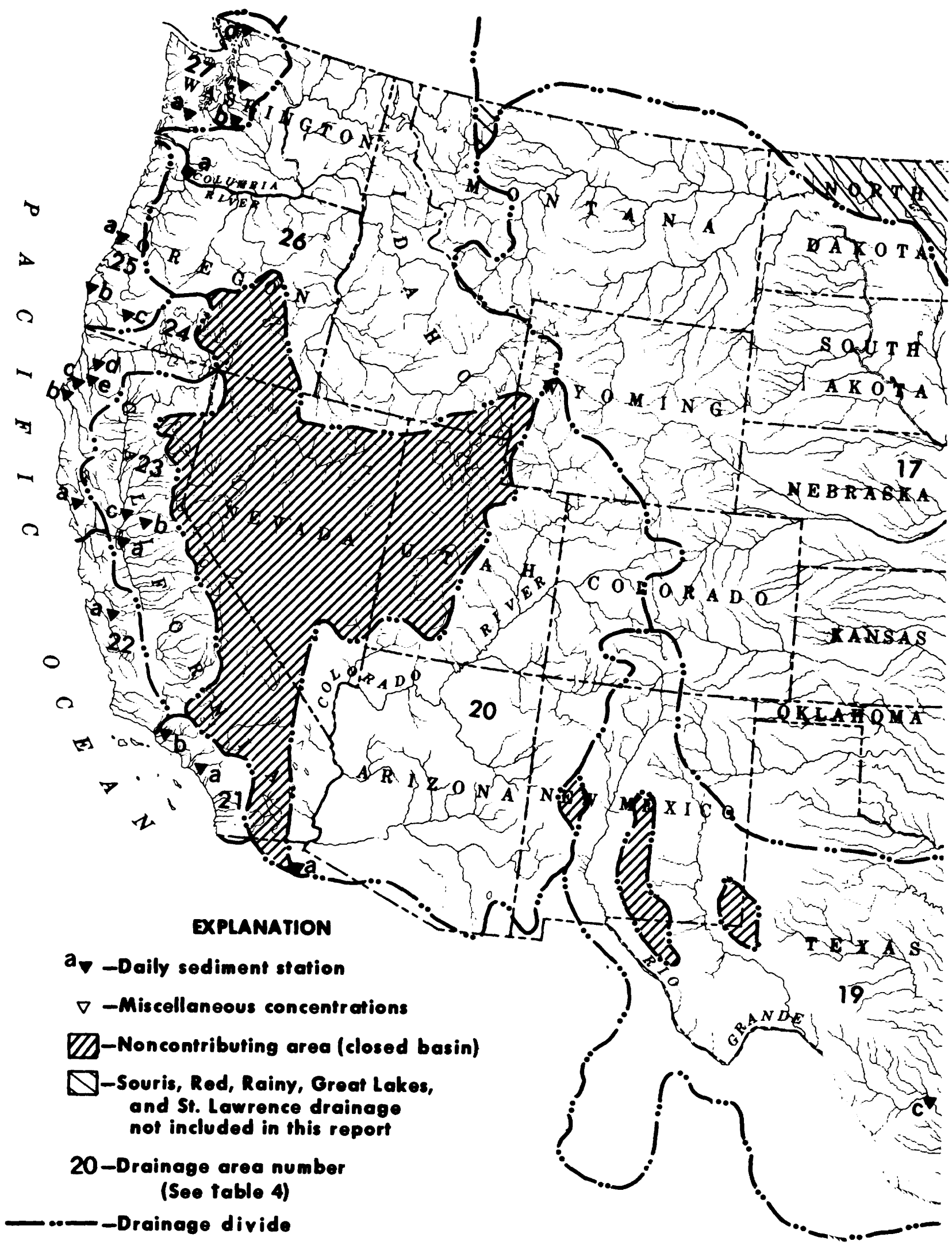

Figure 1 (above and right).-Drainage areas and location of sediment stations. 


\section{PERIOD OF RECORD}

To keep this report as up to date as possible, and yet provide a sufficient period of record for a meaningful average, the 1950-69 period was chosen. Although a longer period of record may be desirable, a 20-year period can be expected to span one or more extreme events, dry and wet years, and is a reasonable base for statistical summary.

All sediment stations (43) selected for this study did not have records covering the full 20year period; however, all records available within this period were used. For those stations with relatively short periods of record that included one or more extreme floods, the average annual suspended-sediment discharge was revised downward to reflect conditions more compatible with the long-term discharge. For example, in 1969, three stations in California experienced a flood of approximately the 100year recurrence interval; thus, the 1969 sediment records for those stations were not used. Also, two other stations, Rouge River at Raygold, Oreg. (25c), and Skagit River near Mt. Vernon, Wash. (27d), each had only 1 year of record, 1912 and 1910, respectively (Van Winkle, 1914a, b) ; these records were used although they were outside the period of record selected for the report. For some of the drainage areas, no continuous records were available and the data presented in table 4 are estimates by the authors from miscellaneous sediment samples, upstream sediment records, and (or) water-sediment relations for adjacent or similar basins; thus, no period of record was given.

\section{SUSPENDED-SEDIMENT DISCHARGE}

The suspended-sediment discharge data presented in this report are based on analyses of samples collected with discharge-weighted suspended-sediment samplers used in the United States ([U.S.] Inter-Agency Committee on Water Resources, Subcommittee on Sedimentation, 1963). These samplers are used to collect representative samples of the entire depth of flow with the exception of a zone (the unsampled zone) between the streambed and about 0.3 to 0.5 foot ( 9 to 15 centimeters) above the streambed. Most of the sediment moved by rivers and streams is held in suspension and is transported at about the mean velocity of flow. The remainder of the sediment moves more slowly on or near the streamber in the unsampled zone and generally is referred to as bedload plus saltation load, or simply unmeasured load. Computations of bedload or unmeasured load may be made using varinus theoretical formulas; however, for long-term estimates, an unmeasured sediment discharg? of 10 percent of the suspended-sediment disch arge frequently is used. Unmeasured load is not included in this report. Figure 2 shows the sampled and unsampled zones in sediment sampling.

Daily sediment discharge, in tons per day, is determined by multiplying water discharge, in cubic feet per second, by the concentration of suspended sediment, in milligrams per liter, times a coefficient and assuming a specific gravity of 2.65 for sediment. Tre daily records are then summed to give the annual sediment discharge. To determine the average annual suspended-sediment discharge at a station, the authors summed the annual sediment discharges and divided that sum by the number of years of record. When there were no longterm records (see "Period of Record") the average annual suspended-sediment discharge for a drainage area was estimated All data are given in English units unless otherwise specified.

For this report, the sediment records used were from the sediment station, in the flowing part of the river above tide, closest to the mouth of the chosen river. The latitude and longitude of the individual stations, the sources of the sediment-discharge data used in computing the average annual suspended-sediment discharge and concentration, and the station identification numbers used by the agency collecting the data and by the Office of Water Data Coordination (U.S. Geological Survey, Otice of Water Data Coordination, 1971) are given in table 5 in the back of the report.

\section{SUSPENDED-SEDIMENT YIELD}

Average annual suspended-sediment yields were computed for the 27 drainage areas and for the areas encompassed by the 43 selected 


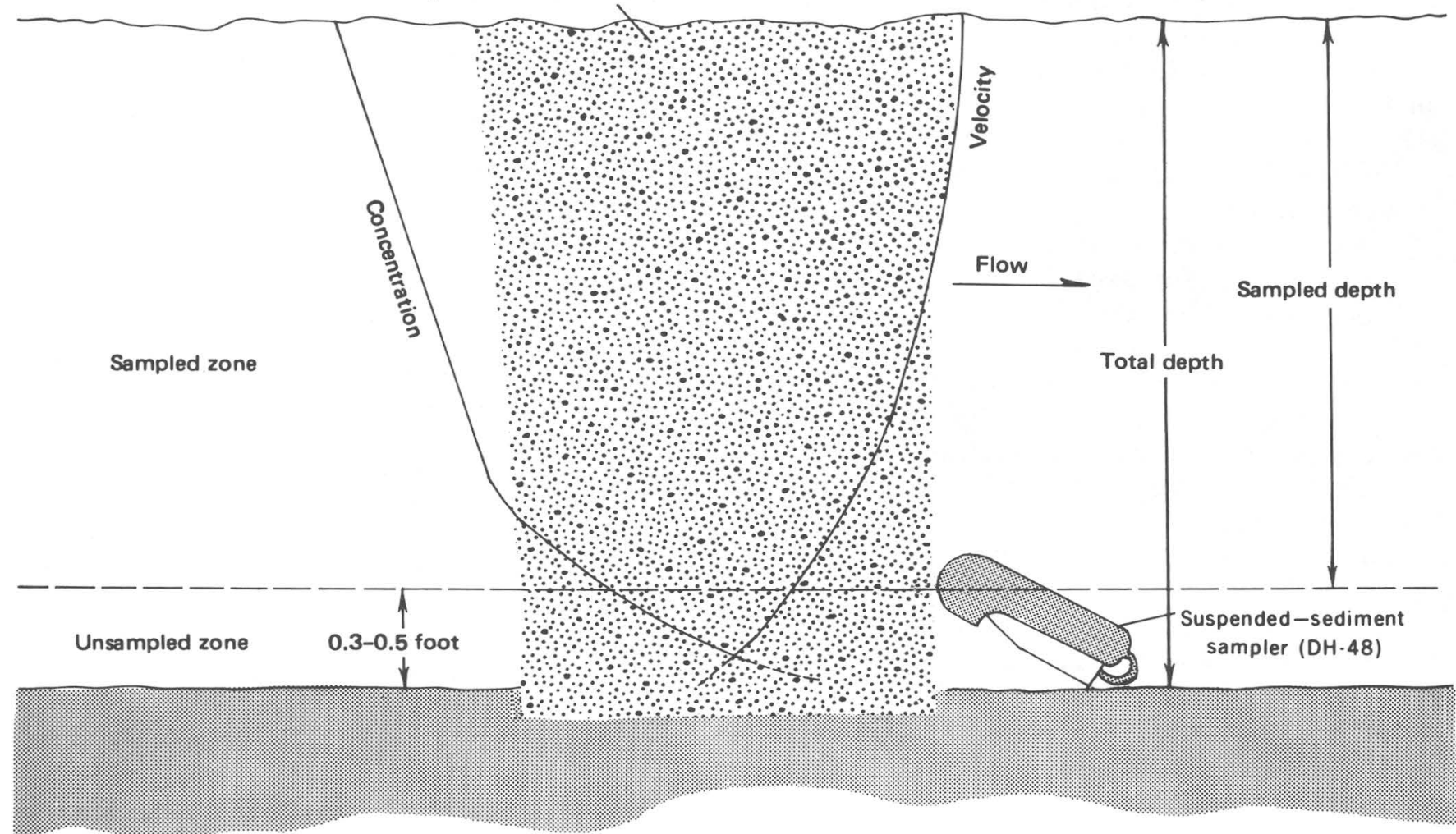

FIGURE 2.-Section of river showing zones of sampled sediment and unsampled sediment (modified from Guy and Norman, 1970).

sediment stations. The sediment yields were determined by dividing the annual average suspended-sediment discharge by the total drainage area. In some instances, the values for sediment yield may be relatively meaningless in terms of the total drainage area because reservoirs and diversions within the area may trap 75 to 95 percent of the sediment. (See "Colorado River Drainage Area.")

\section{SUSPENDED-SEDIMENT CONCENTRATION}

Average annual suspended-sediment concentrations for the 27 major drainages also were computed by dividing the daily average suspended-sediment discharge, in tons, by the daily average water discharge, in cubic feet per second (cfs), and using appropriate conversion factors. As an example, for area 1 where the average annual sediment discharge is 460,000 short tons and the daily average water discharge is $23,500 \mathrm{cfs}$, the conversion factor is
0.0027 , and average annual daily sediment concentration, in milligrams per liter $(\mathrm{mg} / \mathrm{l})$ is computed as follows:

$$
\frac{460,000 \text { short tons }}{365 \text { days } \times 23,500 \mathrm{cfs} \times 0.0027}=20 \mathrm{mg} / 1 .
$$

In the metric system, the water discharge is 665 cubic meters per second (cms), the sediment discharge is 417,000 metric tons, and the conversion factor is $\mathbf{0 . 0 8 6 4}$; thus

$$
\begin{aligned}
& \frac{417,000 \text { metric tons }}{365 \text { days } \times 665 \mathrm{cms} \times 0.0864}=20 \mathrm{mg} / 1 . \\
& \text { SEDIMENT DISCHARGE TO THE } \\
& \text { ATLANTIC OCEAN }
\end{aligned}
$$

Sediment discharge to the Atlantic Ocean was determined for 10 major drainage areas (table $4 A$ ). Of these 10 areas, no long-term sediment records were available for six of the areas, which represent about 46 percent of the total water discharged to the Atlantic Ocean. Thus, estimates of sediment discharge for these six 
areas were based on samples collected intermittently within the areas during 1950-69. Suspended-sediment discharges range from 134,000 tons per year for area 10 to $5,800,000$ tons per year for area 5.

For the 10 areas, the average annual suspended-sediment yields range from about 12 tons per square mile for area 10 to 73.2 tons per square mile for area 5 , which contributes 28.8 percent of the total water discharged and 37.6 percent of the total sediment discharged to the Atlantic Ocean and contains the three river basins that have the highest sediment yields (Delaware River at Trenton, N.J., 111 tons per square mile; Potomac River at Point of Rocks, Md., 81.4 tons per square mile; and Susquehanna River at Harrisburg, Pa., 81 tons per square mile).

The average annual suspended-sediment concentrations for the 10 areas range from $20 \mathrm{mg} / 1$ for area 1 to $58 \mathrm{mg} / 1$ for area 5 . For the entire Atlantic Ocean drainage area the dischargeweighted average annual suspended-sediment concentration is $40 \mathrm{mg} / \mathrm{l}$.

\section{SEDIMENT DISCHARGE TO THE GULF OF MEXICO}

\section{GULF OF MEXICO DRAINAGE AREA}

Sediment discharge to the Gulf of Mexico was determined for nine major drainage areas (table $4 B$ ). Long-term sediment records were not available for four of these areas, and estimates of sediment discharge were based on miscellaneous samples collected at several locations within these areas. The suspended-sediment discharges for the Gulf of Mexico area range from 37,000 tons per year for area 11 to $326,468,000$ tons per year for area 17.

For the nine areas, the average annual suspended-sediment yields range from about 6 tons per square mile for area 11 to 259 tons per square mile for area 17 . Interestingly, the single river basin with the highest sediment yield (Brazos River, Tex., 398 tons per square mile) is in area 19 , whereas area 17 , which has the highest annual tonnage, contains the river basin with the second highest sediment yield.

The average annual suspended-sediment concentrations range from $15 \mathrm{mg} / 1$ for areas 11 ,
12 , and 13 to $820 \mathrm{mg} / \mathrm{l}$ for area 19. Area 17, which has the highest average annual tonnage in the Gulf of Mexico drainage area, has an average annual suspended-sediment concentration of $510 \mathrm{mg} / \mathrm{l}$. For the entire Gulf of Mexico drainage area the discharge-weighted average annual suspended-sediment concentration is $433 \mathrm{mg} / \mathrm{l}$.

\section{MISSISSIPPI RIVER DRAINAGE BASIN}

The Mississippi River drains 1,262,000 square miles $(3,268,580$ square kilometers) or 47.4 percent of the total area covered in this report and contributes about 37 percent of the total amount of water and 66 percent of the suspended-sediment discharge from the conterminous United States. Sediment sampling had been carried on intermittently at different locations along the lower Mississippi River since 1838. At the beginning of the 1950 water year, the U.S. Army Corps of Engineers began a formal continuing program of sediment sampling.

The lower Mississippi River system (fig. 3) is highly controlled and regulated, both for normal flow and flood flow. Prior to 1963, some of the Mississippi River flood flows went into the Red-Atchafalaya system through a connecting channel. In 1963, the Corps of Engineers completed a control structure on the by-pass channel to keep flow in the two river systems separated.

Data for six stations within this complex system were used by the authors in computing the average annual suspended-sediment discharge for the Mississippi and Atchafalaya Rivers. These stations and their periods of record are listed below. Figure 3 shows the location of the six stations, and table 5 gives their latitude and longitude.

$\begin{array}{llc}\text { Station } & \begin{array}{c}\text { Period of } \\ \text { record }\end{array} \\ \text { 1. Mississippi River at Baton Rouge, La }--- & 1950-67 \\ \text { 2. Mississippi River at Red River Landing, } & \\ \text { La } & \\ \text { 3. Mississippi River at Tarbot Landing, La }- & 1963-69 \\ \text { 4. Atchafalaya River at Simmesport, La }-- & 1952-69 \\ \text { 5. Wax Lake Outlet at Calumet, La }-1968-68 \\ \text { 6. Atchafalaya River at Morgan City, La }-- & 1966-68\end{array}$

Data for the three stations on the Mississippi River at Baton Rouge, La., Red River Landing, La., and Tarbot Landing, La., were combined to 


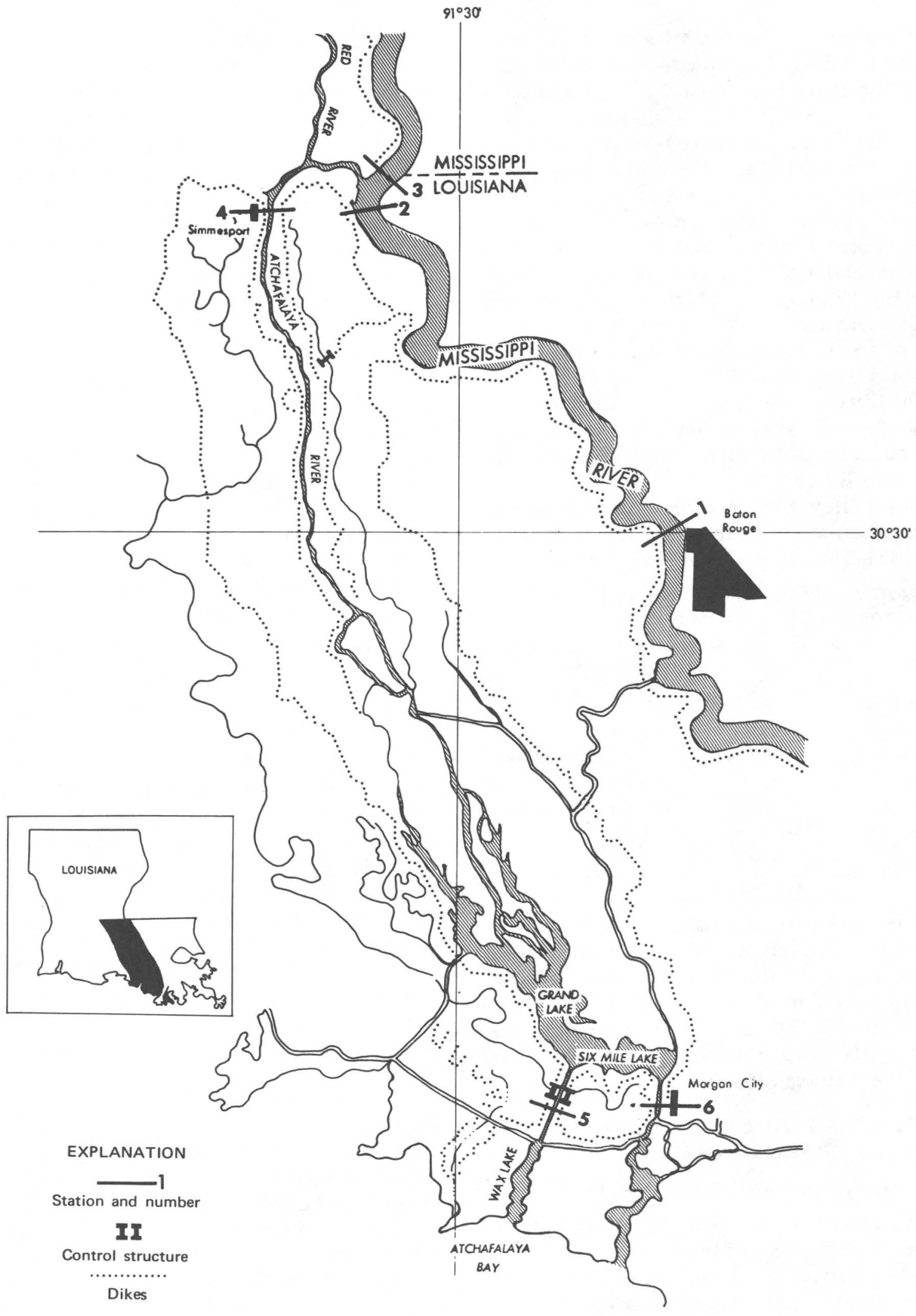

FIGURE 3.-Sketch map of the lower Mississippi River drainage basin showing location of stations used to compute sediment discharge for the Mississippi River (area 17). Numbers correspond to list in text, "Mississippi River Drainage Basin." 
compute the record for the Mississippi River at Red River Landing, La. (station 17a, table $4 B$ ). Data for the three stations on the Atchafalaya River at Simmesport, La., Calumet, La., and Morgan City, La., were used to compute the record for the Atchafalaya suspended-sediment discharge (station $17 \mathrm{~b}$, table $4 B$ ).

A study of the suspended-sediment records for Simmesport, Calumet, and Morgan City indicated that about 31 percent of the sediment passing the Simmesport station was deposited in Grand Lake and Six Mile Lake; therefore, 69 percent of the suspended-sediment discharge at Simmesport for 1950-65 was used and a summation of the Calumet and Morgan City stations for 1966-69 was used in deriving the average annual suspended-sediment discharge for the Atchafalaya River.

Although they were not used in this report, historical sediment-discharge data obtained during 1851-1931 are summarized in table 1. If

TABLE 1.-Historical suspended-sediment discharge data for the lower Mississippi River

[Data from U.S. Army, Corps of Engineers, New Orleans District]

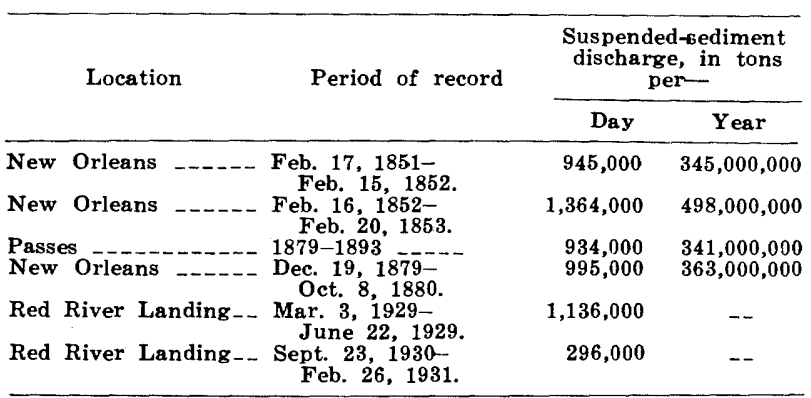

the annual sediment discharges shown are assumed to be relatively accurate, it would appear that the average annual suspended-sediment discharge contributed by the main stem Mississippi River to the Gulf of Mexico has been reduced by about 30 percent during the 100 -year period (1851-1931, 1950-69).

\section{SEDIMENT DISCHARGE TO THE PACIFIC OCEAN}

\section{PACIFIC OCEAN DRAINAGE AREA}

Sediment discharge to the Pacific Ocean was determined for eight major drainage areas (table $4 C$ ). Suspended-sediment discharges for this area range from 10,600 tons per year for area 20 to $67,816,000$ tons per year for area 24 .

Sediment yields from the area draining into the Pacific Ocean in terms of tons per square mile are considerably greater than the yields from areas draining into the Atlantic Ocean or the Gulf of Mexico. The average annual suspended-sediment yields, exclusive of area 20 (Colorado River) range from 60.5 tons per square mile for area 26 to 3,108 tons per square mile for area 24. Area 24, which contains the individual river that has the greatest sediment yield (Eel River, Calif., 9,426 tons per square mile), has the greatest sediment yield for any area draining into the oceans from the conterminous United States.

The average annual suspended-sediment concentrations range from $49 \mathrm{mg} / 1$ for area 27 to $1,634 \mathrm{mg} / 1$ for area 21 . Area 24 has the highest discharge and yield and the second highest sediment concentration $(1,630 \mathrm{mg} / 1)$. For the entire Pacific Ocean drainage area the dischargeweighted average annual suspended-sediment concentration of discharge is $201 \mathrm{mg} / 1$.

\section{COLORADO RIVER DRAINAGE BASIN}

The Colorado River drainage basin (area 20) has the lowest sediment discharge $(10,600$ tons per year) and sediment yield ( 0.04 ton per square mile per year) of any contributing area draining into the oceans from the conterminous United States. However, even with this extremely low sediment yield, the average annual suspended-sediment concentration $(165 \mathrm{mg} / \mathrm{l})$ is greater than that from any contributing area draining into the Atlantic Ocean.

The apparent low sediment yield for this drainage basin is the result of better land-use practices and sediment entrapment in the highly developed reservoir system on the Colorado River. Data for the station Colorado River at Yuma, Ariz., are used to illustrate the dramatic effect these changes have had on the sediment discharge. During 1911-16, the average annual suspended-sediment discharge at Yuma was $234,600,000$ tons (966 tons per square mile). As a result of the development of the reservoir system and the increased use of water for irrigation the suspended-sediment discharge was reduced considerably and for 1965-67 the average annual suspended-sediment discharge was 
152,600 tons (0.63 ton per square mile). At the station used in this report, Colorado River at Miguel C. Rodriguez, Mexico, which is about 52 miles downstream from Yuma, the average annual suspended-sediment discharge for the period 1965-69 was further reduced to 10,600 tons ( 0.04 ton per square mile), largely due to diversion of water for irrigation. Hydrographs of water discharge and suspended-sediment discharge for the Colorado River at Yuma, Ariz., for 1911-67 are shown in figure 4 and clearly indicate the major changes that have occurred during this period.
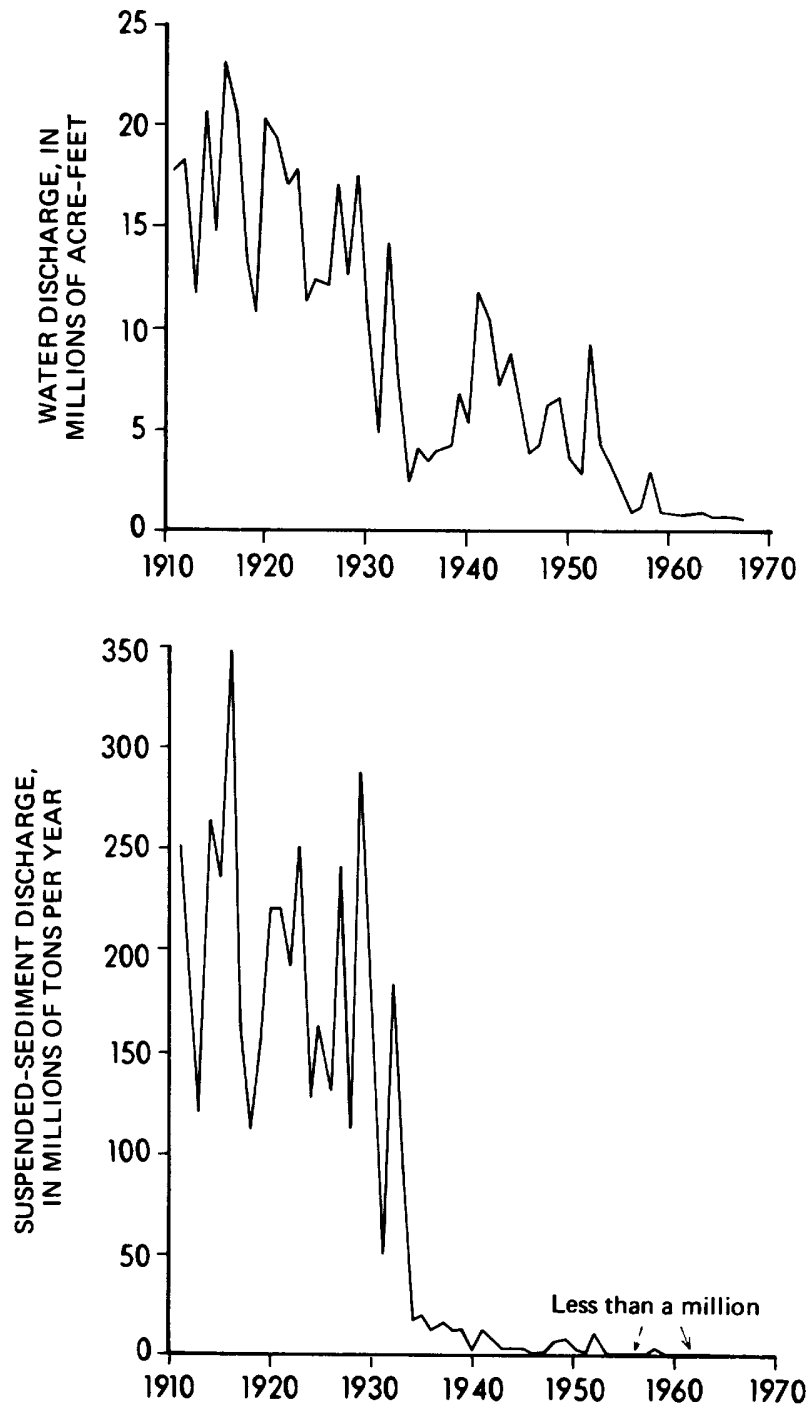

FiguRE 4.-Water discharge and suspended-sediment discharge for the Colorado River at Yuma, Ariz., 1911-67.
COMPARISON OF PRESENT ANI PREVIOUS

ESTIMATES OF SUSPENDED-rEDIMENT

\section{DISCHARGE}

One of the difficulties in comparing present and past estimates of sediment rields is the difference in time periods used and the amount of data available at the time of the various studies. Also, different drainage areas may have been used by the various writers.

Trends of sediment yield for a given river or basin can never be determined verv accurately until long-term records of comparable accuracy are available. As more and more records become available, more accurate and reasonable estimates of sediment yield and rate of denudation can be made. Some comparisons can be made, however, between the data presented in this report and past estimates for several of the major rivers and basins in the United States.

Regional erosion rates in the United States were estimated by Dole and Stabler (1909) and rates of regional denudation of the United States were estimated by Judsor and Ritter (1964). A summary of data comparing estimates of these authors with present estimates is given in table 2. Average annual suspendedsediment discharges given in the table were computed by using the contributing drainage area values given in this report and the sediment yields estimated by the previous authors.

Holeman (1968) presented estiniates of sediment yields of the major rivers of the world. For selected river basins of Nortr America he estimated an average annual suspended-sediment yield of 245 tons per square mile. The total drainage area contributing sediment discharge to the oceans from the United States is $2,658,776$ square miles. Using this drainage area and Holeman's estimate of 245 tons per square mile per year for North America. the average annual suspended-sediment discharge to the oceans from the conterminous I'vited States would be $651,400,000$ tons as compared with $491,449,600$ tons determined by this study. Most of the difference between Holeman's estimate and the authors' is due to the fact that he used the records for the station Color ${ }^{\prime}$ o River at Grand Canyon Ariz., 1925-57, which is upstream of most of the present reservoir system. 
TABLE 2.-Comparison between present and past estimates of sediment yields for selected rivers discharging to the oceans from the conterminous United States

\begin{tabular}{|c|c|c|c|c|c|c|c|}
\hline \multirow{2}{*}{$\begin{array}{l}\text { Area or } \\
\text { river basin }\end{array}$} & \multicolumn{3}{|c|}{$\begin{array}{l}\text { Average annual suspended- } \\
\text { sediment yield, in tons per } \\
\text { square mile }\end{array}$} & \multirow{2}{*}{$\begin{array}{l}\text { Drainage } \\
\text { area, in } \\
\text { square } \\
\text { miles }\end{array}$} & \multicolumn{3}{|c|}{$\begin{array}{l}\text { Average annual suspender- } \\
\text { sediment discharge, in } \\
\text { thousands of tons }\end{array}$} \\
\hline & $\begin{array}{l}\text { This } \\
\text { report }\end{array}$ & $\begin{array}{l}\text { Judson } \\
\text { and } \\
\text { Ritter } \\
(1964)\end{array}$ & $\begin{array}{l}\text { Dole } \\
\text { and } \\
\text { Stabler } \\
(1909)\end{array}$ & & $\begin{array}{l}\text { This } \\
\text { report }\end{array}$ & $\begin{array}{l}\text { Judson } \\
\text { and } \\
\text { Ritter } \\
\text { (1964) }\end{array}$ & $\begin{array}{l}\text { Dole } \\
\text { and } \\
\text { Stab'ex } \\
\left(190^{?}\right)\end{array}$ \\
\hline $\begin{array}{l}\text { Atlantic Ocean: } \\
\text { Delaware River } \\
\text { Susquehanna River } \\
\text { Potomac River } \\
\text { Pee Dee River } \\
\text { Ogeechee River }\end{array}$ & $\begin{array}{c}49.5 \\
111 \\
81.0 \\
81.4 \\
15.2 \\
23.2\end{array}$ & $\begin{array}{r}--\overline{147} \\
---- \\
----\end{array}$ & $\begin{array}{r}97.2 \\
56 \\
35 \\
95 \\
154 \\
225\end{array}$ & $\begin{array}{r}287,166 \\
6,780 \\
24,100 \\
9,651 \\
8,830 \\
2,650\end{array}$ & $\begin{array}{r}14,204 \\
749 \\
1,953 \\
786 \\
442 \\
61.6\end{array}$ & $\begin{array}{r}-\overline{998} \\
---- \\
---- \\
---- \\
----\end{array}$ & $\begin{array}{r}\mathbf{2 7 , 9 0 0} \\
\mathbf{3 8 0} \\
\mathbf{8 4 5} \\
\mathbf{9 1 3} \\
\mathbf{1 , 3 6 0} \\
\mathbf{5 9 6}\end{array}$ \\
\hline $\begin{array}{l}\text { Gulf of Mexico: } \\
\text { Apalachicola River } \\
\text { Tombigbee River } \\
\text { Alabama River } \\
\text { Pearl River } \\
\text { Mississippi River }\end{array}$ & $\begin{array}{l}217.4 \\
10.1 \\
128 \\
115 \\
133 \\
259\end{array}$ & $\begin{array}{r}-120 \\
-\overline{97} \\
-\overline{244}\end{array}$ & $\begin{array}{r}220 \\
159 \\
104 \\
178 \\
58 \\
269\end{array}$ & $\begin{array}{r}1,739,200 \\
17,200 \\
19,200 \\
22,000 \\
6,630 \\
1,262,000\end{array}$ & $\begin{array}{r}378,179 \\
173 \\
2,454 \\
2,528 \\
881 \\
244,900\end{array}$ & $\begin{array}{r}\overline{2} \overline{\mathbf{2}} \overline{\mathbf{3 0 0}} \\
\mathbf{2 , 1 4 0} \\
\mathbf{3 0} \overline{8}, \overline{000}\end{array}$ & $\begin{array}{r}385,600 \\
2,740 \\
2,000 \\
2,920 \\
385 \\
34 C, 000\end{array}$ \\
\hline $\begin{array}{l}\text { Pacilic Ocean: } \\
\text { Colorado River } \\
\text { San Francisco Bay } \\
\text { Sacramento River } \\
\text { Eel River } \\
\text { Mad River } \\
\text { Trinity River } \\
\text { Columbia River }\end{array}$ & $\begin{array}{c}157 \\
75.04 \\
116 \\
9,426 \\
5,549 \\
1,919 \\
60.5\end{array}$ & $\begin{array}{r}623 \\
1,190 \\
-\overline{94} \\
5,846 \\
3,711 \\
1,141 \\
125\end{array}$ & \begin{tabular}{c}
$\mathbf{3 8 7}$ \\
77 \\
86 \\
---- \\
\hdashline--- \\
---
\end{tabular} & $\begin{array}{r}632,410 \\
245,000 \\
47,570 \\
23,530 \\
3,113 \\
485 \\
2,865 \\
258,200\end{array}$ & $\begin{array}{r}99,067 \\
10.6 \\
3,585 \\
2,719 \\
29,345 \\
2,691 \\
5,497 \\
15,620\end{array}$ & $\begin{array}{r}394,100 \\
292,000 \\
\overline{2}, 21 \overline{15} \\
18,200 \\
1,800 \\
3,270 \\
32,300\end{array}$ & 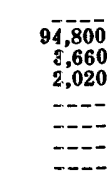 \\
\hline
\end{tabular}

1 Sum of Colorado, Pacific Slopes, California, and Columbia Regions.

Based on the data given in this report, the average annual suspended-sediment yield from the conterminous United States to the oceans is 184.8 tons per square mile.

\section{SUMMARY}

Suspended-sediment discharge data obtained from 27 drainage areas during the period 1950 69 were used to estimate the sediment contributed to the oceans from the conterminous United States. The data are based on suspendedsediment samples obtained with standard United States depth-integrating samplers and, therefore, do not include that part of the total sediment discharge moving as bedload. The quantity of sediment transported as bedload may be estimated at about 10 percent of the sediment transported in suspension.

The amount of sediment discharged each day into the Atlantic and Pacific Oceans is 38,915 tons and 271,400 tons, respectively. The Gulf of Mexico receives about three times more sediment than both of these areas, a total of $1,037,000$ each day. A more pictorial way of expressing these figures is to transport this sediment discharge by train (a boxcar is equivalent to 100,000 pounds or 50 tons). Each day of the year it would take a train of 778 boxcars to transport the suspended-sediment discharged to the Atlantic Ocean and 5,42 ? boxcars to transport the Pacific Coast sediment; to move the Gulf of Mexico sediment, it would take a daily train 20,740 boxcars long.

Average yearly sediment yield's range from 49.5 tons per square mile for the Atlantic Ocean drainage area to 217.4 tons per square mile for the Gulf of Mexico drainage area; the Pacific Ocean drainage area falls into the middle with 156.6 tons per square mile. The mean for the entire conterminous United States (excluding the Great Lakes drainage area) is 184.8 tons per square mile. However, yields comnuted on the basis of total drainage area can be deceiving because good land-use practices and multiple reservoirs in the drainage area can dramatically reduce the amount of sediment delivered to the sea. The Colorado River drainage liasin is a good example. The yield of the station Colorado River at Yuma, Ariz., was reduced from 966 tons per square mile during the period 1911-16 to 0.63 ton per square mile during the period 1965-67.

Concentrations of suspended sediment range from about $15 \mathrm{mg} / \mathrm{l}$ along the sor thern part of the Atlantic Coast to over $1,600 \mathrm{mg} / \mathrm{l}$ along the southern part of the Pacific Coast. The Gulf Coast region has the most drainaco basins with the lowest $(15 \mathrm{mg} / \mathrm{l})$ sediment corcentration.

The amount of suspended-s -diment dis- 
charged to the oceans from the conterminous United States is 491,449,600 tons per year. (See table 3.) If this amount was deposited in Washington, D.C., on the mall between the Capitol and the Lincoln Memorial (an are 11,000 feet long and 600 feet wide), it would roach a depth of about 1,400 feet or $21 / 2$ times a high as the Washington Monument.

TABLE 3.-Summary of suspended-sediment discharge to the oceans from the conterminous United States

[Upper numbers are English units; lower numbers are metric units]

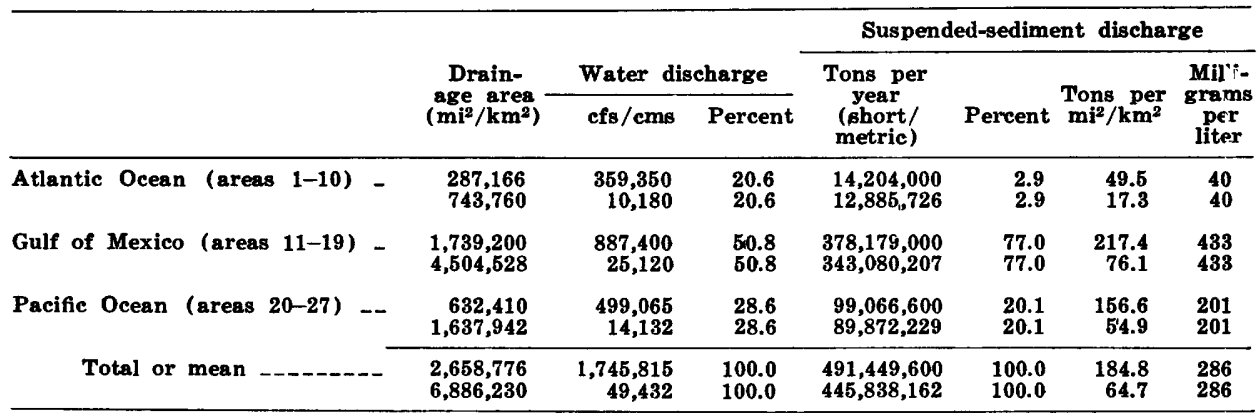

\section{REFERENCES CITED}

Dole, R. B., and Stabler, Herman, 1909, Denudation, in Papers on the conservation of water resources: U.S. Geol. Survey Water-Supply Paper 234, p. 78-93.

Guy, H. P., and Norman, V. W., 1970, Field methods for measurement of fluvial sediment: U.S. Geol. Survey Techniques Water-Resources Inv., book 3, chap. C2, p. 3.

Holeman, J. N., 1968, The sediment yield of major rivers of the world: Water Resources Research, v. 4, no. 4, p. 737-747.

Judson, Sheldon, and Ritter, D. F., 1964, Rates of denudation in the United States: Jour. Geophys. Research, v. 69, no. 16, p. 3395-3401.

U.S. Geological Survey, Office of Water Data Coordination, 1971, Catalog of information on water data, edition 1970-Index to water quality data: Washington, D.C., U.S. Geol. Survey, 443 p.
[U.S.] Inter-Agency Committee on Water Resources, Subcommittee on Sedimentation, 15 33, Determination of fluvial sediment discharge, in A study of methods used in measurement and analysis of sediment loads in streams: Minneapolis, Minn., St. Anthony Falls Hydrol. Lab. Rept. 14, 151 p.

Van Winkle, Walton, 1914a, Quality of the surface waters of Washington: U.S. Geol. Survey WaterSupply Paper 339.

$1914 \mathrm{~b}$, Quality of the surface waters of Oregon: U.S. Geol. Survey Water-Supply Paper 363.

Williams, K. F., and Reed, L. A., 197\%. Appraisal of stream sedimentation in the Susquehanna River basin: U.S. Geol. Survey Water-Supply Paper 1532-F.

Wilson, Alfonso, and Iseri, K. T., 1967 (revised 1969), River discharge to the sea from th? shores of the conterminous United States, Alasla, and Puerto Rico: U.S. Geol. Survey Hydrol. Inv. Atlas HA282. 

TABLES 4 AND 5 
TABLE 4.-Suspended-sediment discharge from the conterminous United States to the Atlantic Ocean, Gulf of Mexico, and the Pacific Ocean

[Drainage area and water-discharge data from Wilson and Iseri (1967); asterisk $\left(^{*}\right)$ indicates revised data (Alfonso Wilson and $K$. T. Iseri, oral commun., 1971). E= estimated. N.d. = not determined]

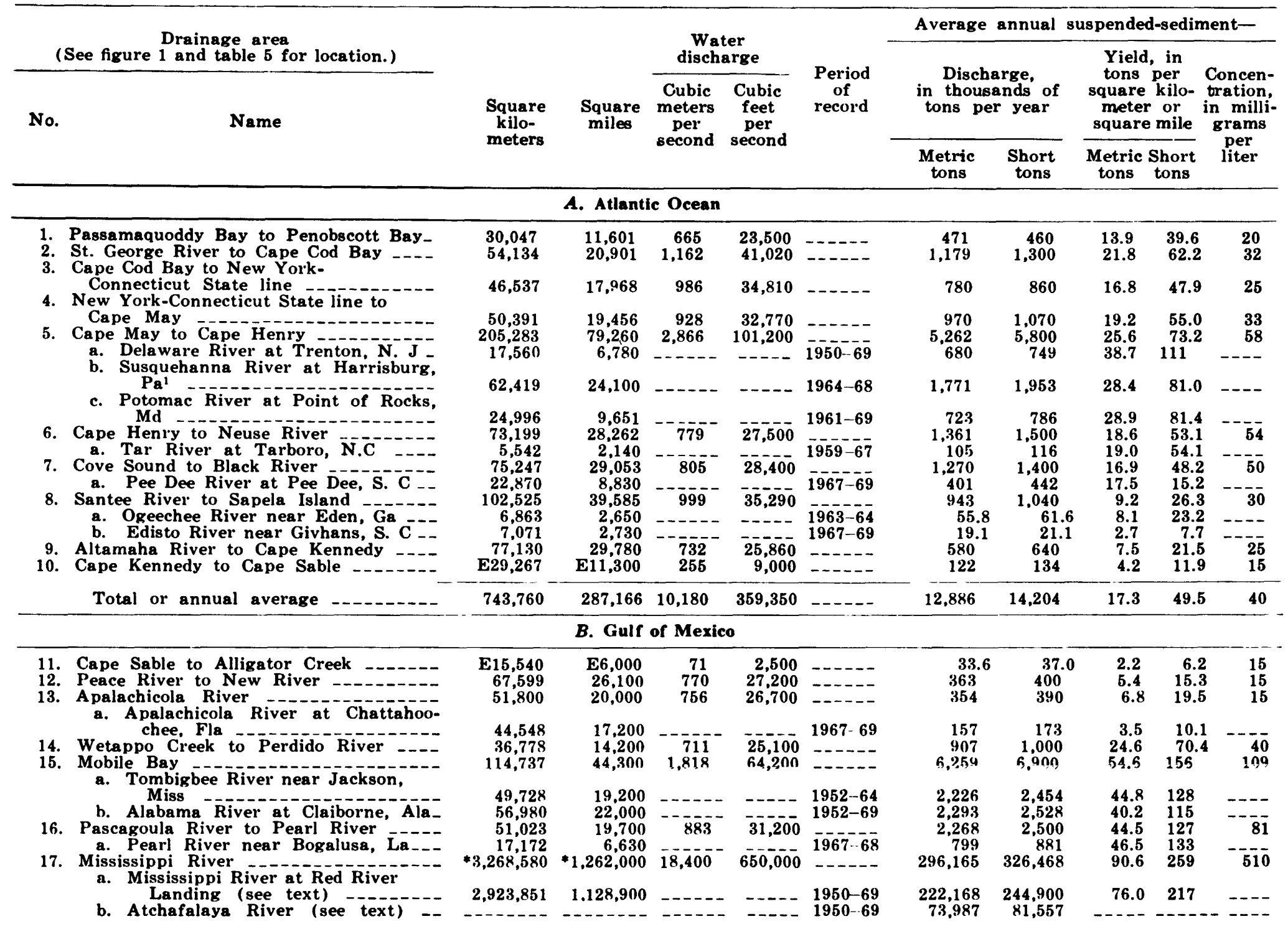


18. Vermilion, Mermentau, and Calcasieu

19. Sabine River to Rio Grande

a. Brazos River at Richmond, Tex

b. Colorado River at Columbus, Tex

c. Nueces River near Three Rivers, Tex - Colorado at Mercedes, Tex. Rio Grande near Brownsville, Tex.. North Floodway near Sebastian, Tex.

Total or annual average _..--

22,533

875,938

114,012

106,371

40,404

N.d.

N.d.

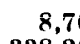

8,700

$300 \quad 306$

$\begin{array}{rr}338,200 & 1,407\end{array}$

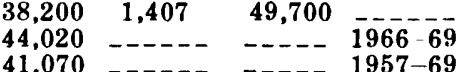

- - - $1957-69$

1951-52

N.d.

$4,504,528$

N.d.

N.d

N.d. $\quad 1966-69$ 887,400 C. Pacific Ocean

20. Colorado River

a. Colorado River at Miguel C.

Rodriquez, Mexico

21. Tia Juana River to Ventura River

a. San Juan Creek near San Juan

b. Santa Clara River at Saticoy, Calif

22. San Jose Creek to Pesadero Creek

a. Salinas River near Spreckels,

23. San Francisco Bay

a. San Joaquin River near Vernalis,

b. Consumnes River at Michigan Bar,

Calif
Calif

24. Lagunitas Creek to Smith River -..-

a. Russian River near Guerneville,

b. Eel River at Scotia, Calif -

c. Mad River at Arcata, Calif

d. Klamath River at Orleans, Calif -

e. Trinity River near Hoopa, Calif :-

25. Oregon coastal area - - -----

a. Siuslaw River near Mapleton, Oreg

c. Rouge River at Raygold, Oreg --

26. Columbia River

a. Columbia River at Vancouver,

27. Naselle River to Nooksack River

a. Chehalis River at Porter, Wash -

b. Skykomish River at Monroe, Wash

c. Snoqualmie River near Carna-

tion, Wash $-1-1-$

\begin{abstract}
ash -
\end{abstract}
634,550

634,550

31,572

275

4,131
28,801

28,801

10,767

35,069

1,388

60,943

56,514

3,471

8,063
1,256

22,015

7,420

43,771

1,523
300

5,317

668,738

624,190

50,790

3,351

2,160

1,562

8,011

245,000

245,000

12,190
0

1.8

65

$--$

106

14

500

0 -

$\begin{array}{r}1,595 \\ 11,120\end{array}-\frac{-18-}{68}-\overline{2,400} \quad 1968$

$\begin{array}{r}4,157 \\ * 45,570\end{array}-\overline{861} \quad-\overline{30,400} 1966-68$

13,540 _... _.

536 _... _- $1963-69$

23,530 _.

$21,820 \quad 1,192 \quad 42,100$

1,340 - $--1 \quad \ldots-1958-69$

3,113 -

485 _-

8,500 -

$2,865-1968-69$

$16,900 \quad \overline{1,509} \quad \overline{53,300}-\overline{1968-69}$

588 - $1,-0-1968-69$

116 - . -

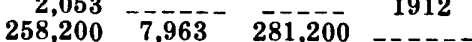

$241,000-----\quad---1964-69$

$19,610 \quad 2,523 \quad 89,100$

1,294

$834-\cdots-\cdots-\cdots-1962-68$

603 -

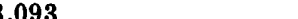

$1,637,942 \quad 632,410 \quad 14,131.8 \quad 499,065 \quad \ldots \ldots$

1 Three dams between station and mouth of river (Williams and Reed, 1972).

2 Tributary to Klamath River.

$\begin{array}{rrrrr}816 & 900 & 36.3 & 103 & 85 \\ 36,400 & 40,124 & 41.6 & 119 & 820 \\ 15,893 & 17,519 & 139 & 398 & --- \\ 1,901 & 2,096 & 17.9 & 51 & ---\end{array}$

$445 \quad 491 \quad 11.0 \quad 31.5 \quad \ldots$

$1,229 \quad 1,355 \quad$ N.d. $\quad$ N.d. \begin{tabular}{lllll}
\hline 343,080 & 378,179 & 76.1 & 217.4 & 433
\end{tabular}

$\begin{array}{lllll}9.6 & 10.6 & 0.015 & 0.04 & 165\end{array}$

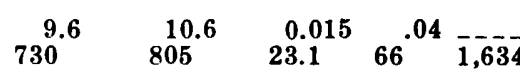

$85.5 \quad 94.3 \quad 311 \quad 890 \quad \ldots$

$\begin{array}{rrrrr}68.7 & 75.7 & 16.6 & 47.5 & \overline{115}-\overline{5} \\ 3,320 & 3,660 & 115 & 329 & \end{array}$

$\begin{array}{rrrrr}531 & 586 & 49.3 & 141 & - \\ 3,252 & 3,585 & 26.4 & 75.4 & 120\end{array}$

$\begin{array}{llll}350 & 386 & 10 & 28.5\end{array}$

$143 \quad 158 \quad 103 \quad 295 \quad \ldots$

$2,464 \quad 2,719 \quad 40.4 \quad 116 \quad \ldots$

$\begin{array}{lllll}61,521 & 67,816 & 1,089 & 3,108 & 1,630\end{array}$

$\begin{array}{rrrrr}4,135 & 4,559 & 1,191 & 3,402 & ---\end{array}$

$\begin{array}{lrlll}2,441 & 2,691 & \mathbf{1 , 9 4 4} & \mathbf{5 , 5 4 9} & --\end{array}$

$\begin{array}{lllll}2,389 & 2,631 & 108 & 310 & --\end{array}$

$\begin{array}{lllll}4,987 & 5,497 & 672 & 1,919 & --- \\ \mathbf{2}, 993 & 3,300 & 68.3 & 195\end{array}$

$\begin{array}{lllll}104 & 3,300 & 68.3 & 195 & 63\end{array}$

$\begin{array}{lllll}104 & 114 & 68.3 & 193.9 & - \\ 199 & 220 & 663 & 1,897 & ---\end{array}$

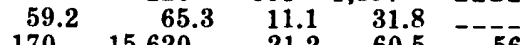

$14,170 \quad 15,620$

$\begin{array}{rrrrr}9,704 & 10,697 & 15.5 & 44.4 & -- \\ 3,873 & 4,270 & 76.3 & 218 & 49\end{array}$

\begin{tabular}{rrrrr}
115 & 4,270 & 76.3 & 218 & 49 \\
\hline & 127 & 34.3 & 97.8 & ---
\end{tabular}

$244 \quad 269 \quad 113 \quad 323$

$263 \quad 290 \quad 168 \quad 481 \quad \ldots$

$\begin{array}{lllll}330 & 364 & 41.2 & 118 & -\end{array}$

$\begin{array}{lllll}89,872.2 & 99,066.6 & 54.9 & 156.6 & 201\end{array}$ 
[OWDC, U.S. Geological Survey, Office of Water Data Coordination. Agency collecting data: GS, U.S. Geological Survey; CE, U.S. Army Corps of Engineers; IBW, International Boundary and Water Commission]

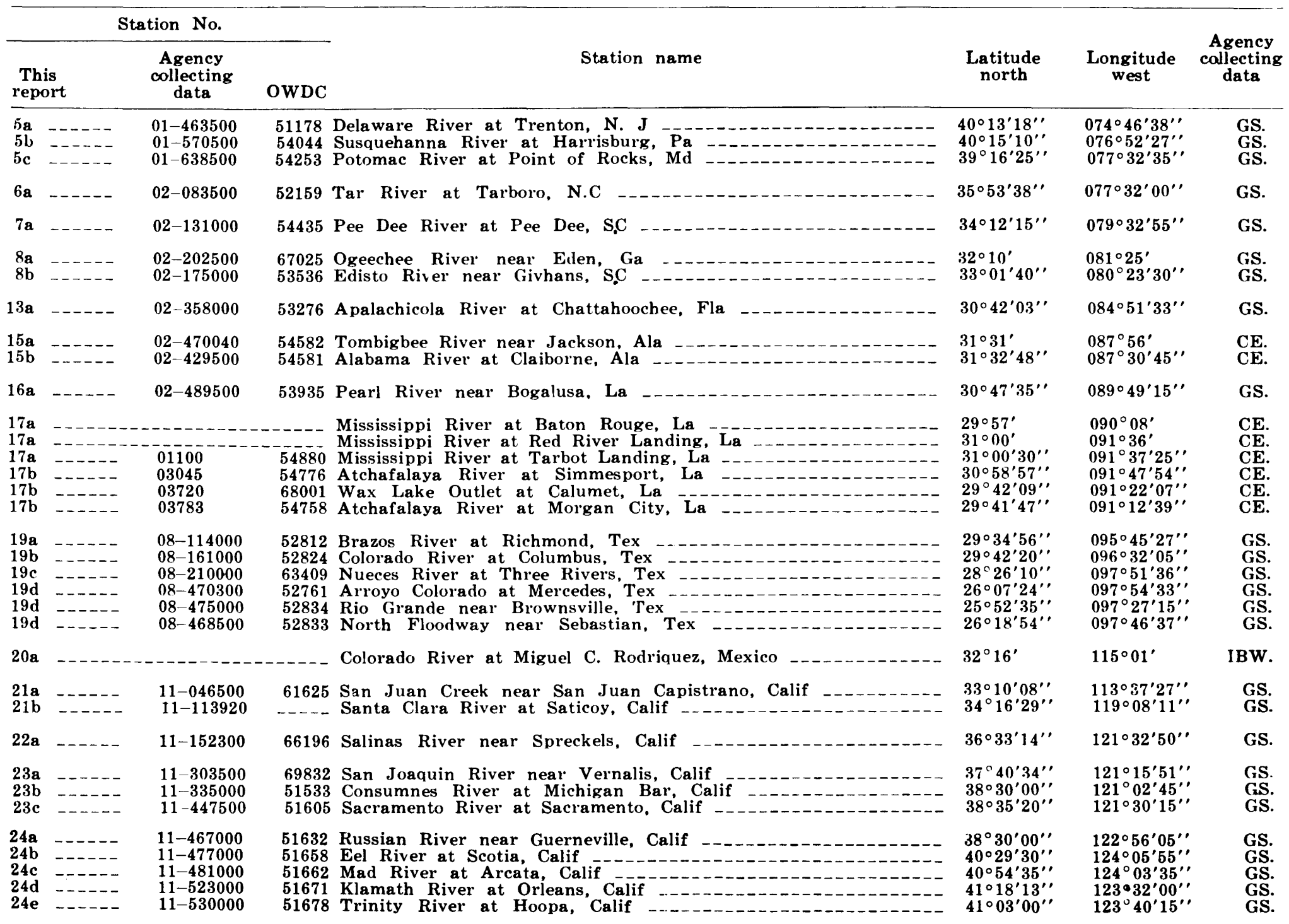


25a

$26 \mathrm{a}$

$27 \mathrm{a}$

$27 \mathbf{b}$

$27 \mathrm{c}$

27d

67 Sixes Rixer at Sixes, Oreg

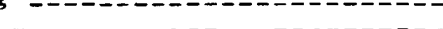

54203 Columbia River at Vancouver, Wash

14-144700

$12-031000$

12-141100

$12-149000$

51906 Chehalis River at Porter, Wash

Skykomish River at Monroe, Wash

51963 Skagit River near Mt. Vernon, Wash

$44^{\circ} 03^{\prime} 45^{\prime \prime} \quad 123^{\circ} 52^{\prime} 55^{\prime \prime}$ 42.4905

$45^{\circ} 37^{\prime} 15^{\prime \prime}$

$122^{\circ} 40^{\prime} 20^{\prime \prime}$

$46^{\circ} 56^{\prime} 20^{\prime \prime} \quad 123^{\circ} 18^{\prime} 45^{\prime \prime}$

$47^{\circ} 50^{\prime} 48^{\prime \prime}$

$123^{\circ} 18^{\prime} 45^{\prime}$
$121^{\circ} 58^{\prime} 10^{\prime \prime}$

$121^{\circ} 55^{\prime}$

$122^{\circ} 20^{\prime} 25^{\prime \prime}$
GS.

GS.

GS.

GS.

GS.

GS. 


$$
+
$$

